\title{
Integrating of Remote Sensing and Airborne Magnetic Data to Outline the Geologic Structural Lineaments That Controlled Mineralization Deposits for the Area around Gabal El-Niteishat, Central Eastern Desert, Egypt
}

\author{
Reda A. Y. El-Qassas, Salem B. Ahmed, Hussein F. Abd-ElSalam, Atef M. Abu-Donia \\ Nuclear Materials Authority, Maadi, Cairo, Egypt \\ Email: redaelqassas@yahoo.com
}

How to cite this paper: El-Qassas, R.A.Y., Ahmed, S.B., Abd-Elsalam, H.F. and Abu-Donia, A.M. (2021) Integrating of Remote Sensing and Airborne Magnetic Data to Outline the Geologic Structural Lineaments That Controlled Mineralization Deposits for the Area around Gabal El-Niteishat, Central Eastern Desert, Egypt. Geomaterials, 11, 1-21.

https://doi.org/10.4236/gm.2021.111001

Received: December 17, 2020

Accepted: January 19, 2021

Published: January 22, 2021

Copyright $\odot 2021$ by author(s) and Scientific Research Publishing Inc. This work is licensed under the Creative Commons Attribution International License (CC BY 4.0).

http://creativecommons.org/licenses/by/4.0/

\section{(c) (i) Open Access}

\begin{abstract}
The Gabal (G.) El-Niteishat area lies in the Central Eastern Desert of Egypt which is known for various mineral resources and geological structures. Umm Gheig, Umm Naggat, Umm Shaddad, Wadi (W.) Zeidun and Sigdit represent some important regions that contain mineral deposits in the study area. Various filters such as first vertical derivative (FVD), horizontal gradient magnitude (HGM), tilt derivative (TDR) and near-surface were applied to the airborne magnetic data for the study area to deduce the structural lineaments and magnetic source edges which were controlled by the presence of mineral deposits. Processed Landsat ETM+ images are used for delineating the rock unit boundaries that are exposed in the study area such as serpentinite, metagabbro, metavolcanics and metasediments. Also, band ratios, principal component analysis (PCA) and false-color composite image (Crosta alteration image) were applied to get specific results about the alteration zones. The structural lineaments analysis illustrated that the common trends that affected the study area were NW-SE, NE-SW, E-W and N-S. Integration of remote sensing and airborne magnetic data exhibited the relation between mineralization and structural lineaments.
\end{abstract}

\section{Keywords}

Remote Sensing, Airborne Magnetic, Mineral Exploration, Umm

Naggat-Umm Gheig, Central Eastern Desert of Egypt 


\section{Introduction}

The study area lies in the Central Eastern Desert of Egypt, between latitudes $25^{\circ} 22^{\prime}$ and $25^{\circ} 42^{\prime} \mathrm{N}$ and longitudes $33^{\circ} 53^{\prime}$ and $34^{\circ} 27^{\prime} \mathrm{E}$ (Figure 1). The study area reveals a special importance, as it comprises rock units, which show some indication of the presence of various mineralization ( $\mathrm{Au}, \mathrm{Cr}, \mathrm{Ta}, \mathrm{Nb}, \mathrm{Sn}, \mathrm{Pb}, \mathrm{Zn}, \mathrm{Cu}$, $\mathrm{Fe}$ and others) as detected by the previous geological, geochemical and geophysical studies.

Ghieth (1995 and 1998), studied G. El Sebai and G. Abu Iteila areas using airborne spectrometric and magnetic data. He concluded that the WNW-ESE, NW-SE, NNW-SSE, N-S, NE-SW and ENE-WSW faults represented the major structures. Also, the study revealed the enrichment of uranium and thorium were related to the occurrence of $\mathrm{Nb}, \mathrm{Ta}$ and $\mathrm{Sn}$ minerals, especially at the contact of granitic pluton in G. Atawi [1] [2].

Gaafar (2015), studied Umm Naggat area, he found that four regional structural trends NNW-SSE, NW-SE, ENE-WSW and E-W played the main important role in $\mathrm{Nb}, \mathrm{Ta}$ [3], $\mathrm{U}$ mineralization. Alteration processes are associated with NW-SE and N-S trends in Umm Naggat [4].

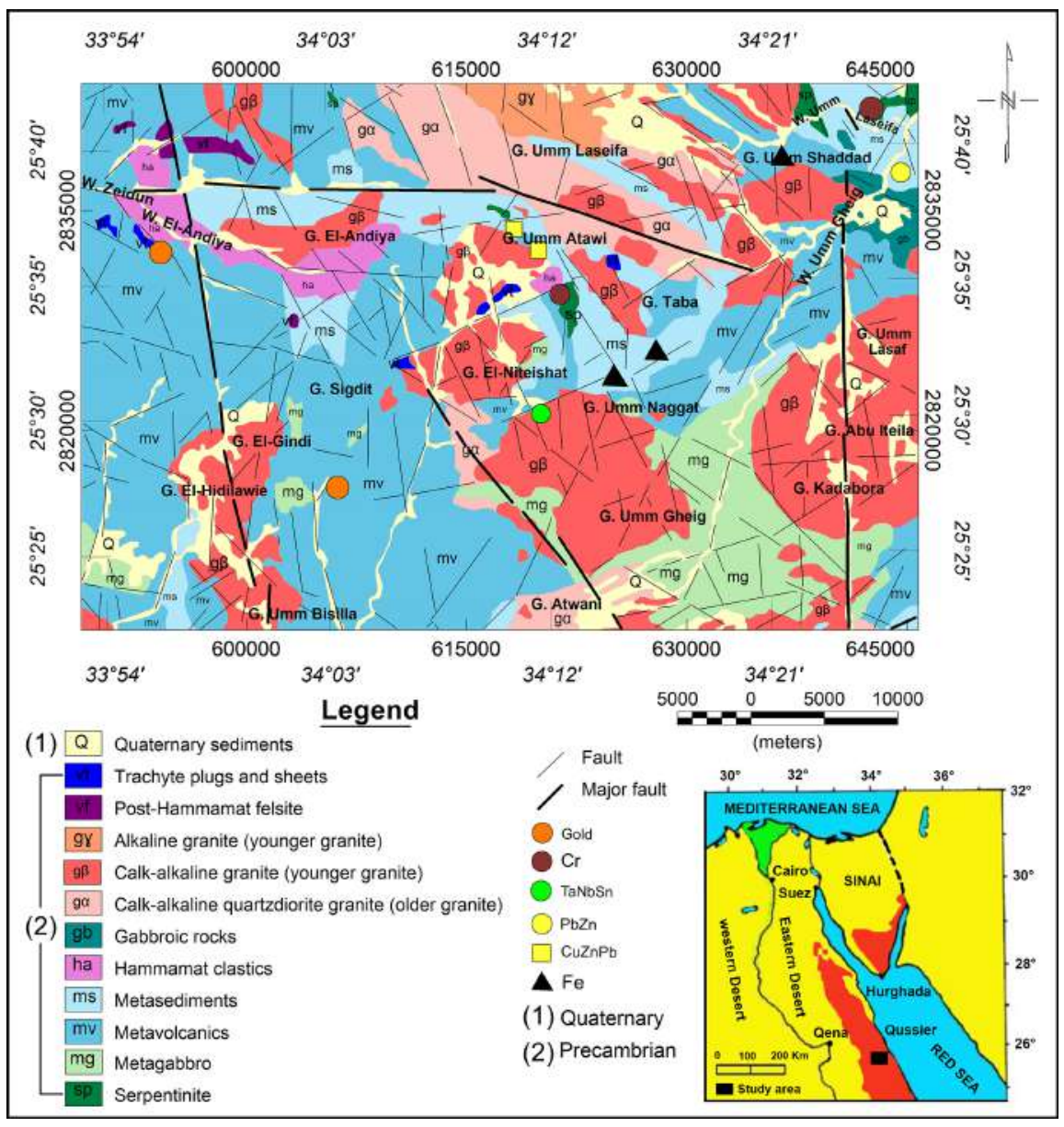

Figure 1. Location and geologic map of the area around G. El-Niteishat, Central Eastern Desert, Egypt (Reproduced after Conoco Coral and EGPC, 1987; EGSMA, 1983). 
Aboelkhair et al. (2014 and 2020) studied Kadabora granite through the integration of airborne spectrometric data remote sensing data. The study concluded that the concentrations of uranium mineralization were controlled by faults trending in the N-S direction [5] [6].

Mineral exploration depends on a complete integration of works, where it starts from searching for new mineral deposits then evaluates the economic importance. It also includes the augmentation of additional ore reserves and resources in the mine and total mining district [7]. Geophysical survey supplements the quick and cost-effective paths to identify the subsurface objects and prioritizing the drill targets [7].

Magnetic method can be useful in detecting magnetic anomalies which may represent ore. Also, it is used in different applications such as locating faults, folds, shear zones, contact and determining geological structures that may play a role in mineral exploration [8] [9] [10] [11].

Multi-resource geospatial data such as geophysical and geochemical information and analysis of satellite images were applied for lithological and mineral mapping, exploiting the development of remote sensing that provided the type of minerals of the different rock units [12] [13].

The current study aims to exploit remote sensing and airborne magnetic data to determine alteration zones of mineralization and structural lineaments that may have a role in the mineral exploration in the study area.

\section{Geologic Setting}

The geologic setting of the study area is mainly based on the geology of Hamata, Egypt of scale 1:500,000 (Conoco Coral and EGPC, 1987) [14] and metallogenic map of Aswan quadrangle, Egypt [15] (Figure 1). The exposed rock units in this area are mostly serpentinite, metagabbro, metavolcanics, metasediments, Hammamat clastics, gabbroic, older granites, younger granites, Post-Hammamat felsite, trachyte plugs and sheets (Figure 1). The outcrops of the different rock units are traversed by many valleys filled with Quaternary sediments. A digital elevation model (DEM) map was used for representing the different elevations in the study area (Figure 2).

The study area is characterized by groups of geological structures related in the concentration deposit mineralizations as gold $(\mathrm{Au})$, chromium $(\mathrm{Cr})$, lead $(\mathrm{Pb})$, zinc $(\mathrm{Zn})$, iron $(\mathrm{Fe})$, copper $(\mathrm{Cu})$ and many other economic minerals. Some of the most important regions in this area, which must be studied carefully because they contain gatherings of economic ore deposits are Umm Gheig, Umm Naggat, Umm Shaddad, Wadi (W.) Sitra, W. Zeidun, Sigdit and Umm Ghamis and many other important regions [3] [16] [17] [18] [19].

The study area includes many minor structural features associated with ore deposits and mineralization, these minor structures are related to the major structures in the area such as the Arabian Nubian Shield (ANS) and Najd faults zone. Hamimi et al. (2015b) concluded that the rifting of the Red Sea from 


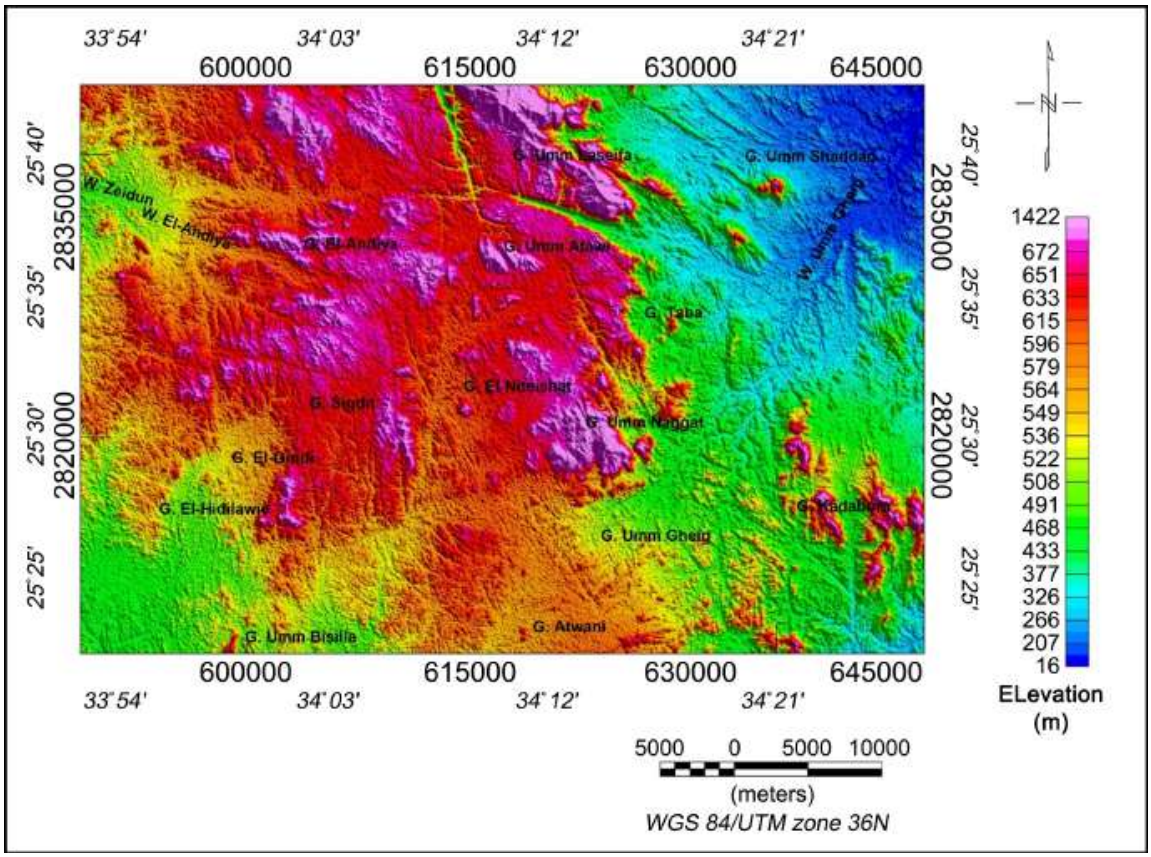

Figure 2. Digital elevation model (DEM) of the area around G. El-Niteishat, Central Eastern Desert, Egypt.

Oligocene and younger times led to uplifting and exhibition of the Neoproterozoic ANS. In the Central Eastern Desert, the fold-related faults are common and associated with pull-apart connected to the Najd system [20].

The Central Eastern Desert (CED) is the most known for its low topography, good roads and mineral resources. The CED consists mainly of Late Tonian-Cryogenian superstructures $(\sim 700-750 \mathrm{Ma})$. Particular attention is paid to the subhorizontal shear zone so-called the Eastern Desert Decollement (EDD), which was active during Najd strike-slip deformation $(\sim 600 \mathrm{Ma})$. Fluid infiltration accompanying superstructure deformation and infrastructure magmatism were responsible for generating most of ED gold deposits [21].

\section{Data Acquisition and Methodology}

Airborne magnetic data of the area under study was included in the segment of area II, which was measured by Aero-Service Division, Western Geophysical Company of America (1984). This survey was conducted over Sothern, Central and Northern Eastern Desert of Egypt to recognize and estimate the groundwater, mineral, petroleum resources (Aero-Service, 1984). The flight lines oriented in northeast-southwest direction, with spacing $1 \mathrm{~km}$ and azimuth of $45^{\circ}$ and $225^{\circ}$ from the north. The Tie lines were oriented in a northwest-southeast direction, with the azimuth of $135^{\circ}$ and $315^{\circ}$, and spacing of $10 \mathrm{~km} \mathrm{[22].}$

The airborne magnetic survey data of the study area were subjected to various methods of processing and analysis through the application of some integrated magnetic techniques to map the structural lineaments as evidence for mineral exploration, these techniques include first vertical derivative (FVD), horizontal 
gradient magnitude (HGM), tilt derivative (TDR) and near-surface. These techniques are considered good tools to delineate near-surface magnetic lineament features such as shear zones, contacts, dykes and faults, which may associate with mineral deposits.

- The algorithm of the vertical derivative is given by [23] as follows:

$$
M(x, y)=M(x, y) \sqrt{\left(\left(x^{2}+y^{2}\right) / n\right)^{n}}
$$

where $n$ is the order of the derivative.

- The horizontal gradient magnitude $\operatorname{HGM}(x, y)$ for the magnetic field $\operatorname{M}(x, y)$ is given by [24] [25].

$$
\operatorname{HGM}(x, y)=\sqrt{(\partial M / \partial x)^{2}+(\partial M / \partial y)^{2}}
$$

- The tilt derivative (TDR) technique was described by [26],

$$
\mathrm{TDR}=\tan ^{-1}\left(\frac{\mathrm{VDR}}{\mathrm{HGM}}\right)
$$

where the vertical derivative is VDR and total horizontal derivatives are HGM.

The main objectives for using the remote sensing images Landsat Enhanced Thematic Mapper (ETM+) are mapping the rock units and to identify the alteration zones in the study area. The Envi and Arc GIS software packages are used to enhance and analyze these data.

\section{Results and Discussions}

\subsection{Interpretation of Airborne Magnetic Data}

The reduced to north magnetic pole (RTP) map (Figure 3) is characterized in general by magnetic values ranging from $41,930 \mathrm{nT}$ to $43,625 \mathrm{nT}$. It displays three zones of magnetic anomalies (high, intermediate and low). High magnetic anomalies are located at the eastern, western, northern and southern parts of the study area. These anomalies have circular or semi-circular, linear and elongated shapes (Figure 3). The circular or semi-circular high magnetic anomalies are located at the western part (south W. Zeidun, at G. El-Gindi and southwest G. El-Hidilawie) and also observed at the eastern part (south G. Kadabora and north G. Umm Lasaf). While, the linear and elongated shape high magnetic anomalies are spread out over the study area and follow NW-SE, NNW-SSE, NE-SW and E-W directions (Figure 3). The high magnetic anomalies are related to surface or subsurface intrusions of basic rocks as serpentinite and metagabbro.

Intermediate magnetic anomalies (yellow to green colour) appeared all over the investigated area (Figure 3). The surface geology refers to that these anomalies are related to metasediments, metavolcanics, post-Hammamat felsite and granite. 


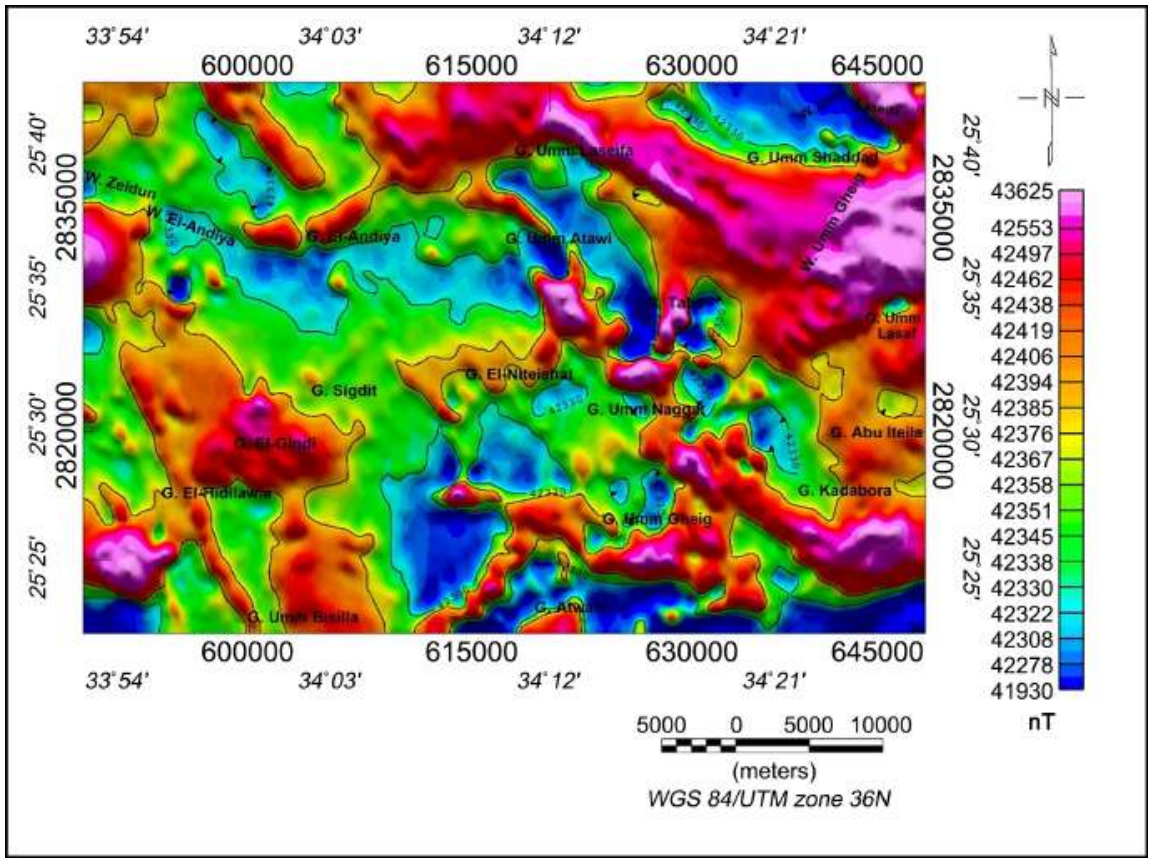

Figure 3. Reduced to the north pole (RTP) airborne magnetic map of the area around G. El-Niteishat, Central Eastern Desert, Egypt (Aero-Service, 1984).

Low magnetic anomalies (light and dark blue colour) are ellipsoid and elongated shapes. These anomalies occurred at the southern, east-central, northern and northeastern parts of the study area (Figure 3). They are belonging to metavolcanics, metasediments, post-Hammamat felsite and some parts of granitic rocks.

\subsubsection{Radially Averaged Power Spectrum}

A separation filter was applied on the RTP airborne magnetic map where the regional and residual magnetic-component maps are obtained at 0.12 cycle/K-unit. The estimated average depths for the shallow and deep magnetic sources as calculated from the power spectrum curve are $700 \mathrm{~m}$ and $1800 \mathrm{~m}$ respectively (Figure 4).

\subsubsection{Residual and Regional Airborne Magnetic Maps}

The high pass (residual) magnetic map of the study area shows high (positive) and low (negative) magnetic features (Figure 5). These features have different sizes, amplitudes, and frequencies with pattern trends taking NW-SW, NE-SW and NNE-SSW directions. A good correlation was found between RTP and residual maps (Figure 4 and Figure 5), which reflects that most of the magnetic source bodies are situated on the surface and/or at shallow depths. The locations of the high magnetic features in the residual map agree well with the effect of these features on the RTP map.

The low pass (regional) magnetic map (Figure 6) displays high and low magnetic features with different sizes, amplitudes and directions. The high magnetic features are recorded at the eastern, western and southern parts of the study 
area. Meanwhile, low magnetic features are situated in the central, southern and northeastern parts. The locations of the high magnetic features on the regional magnetic map agree well with their locations on RTP and residual maps, which suggest that the causative magnetic bodies of these features have shallow depths with deep roots (Figure 6).

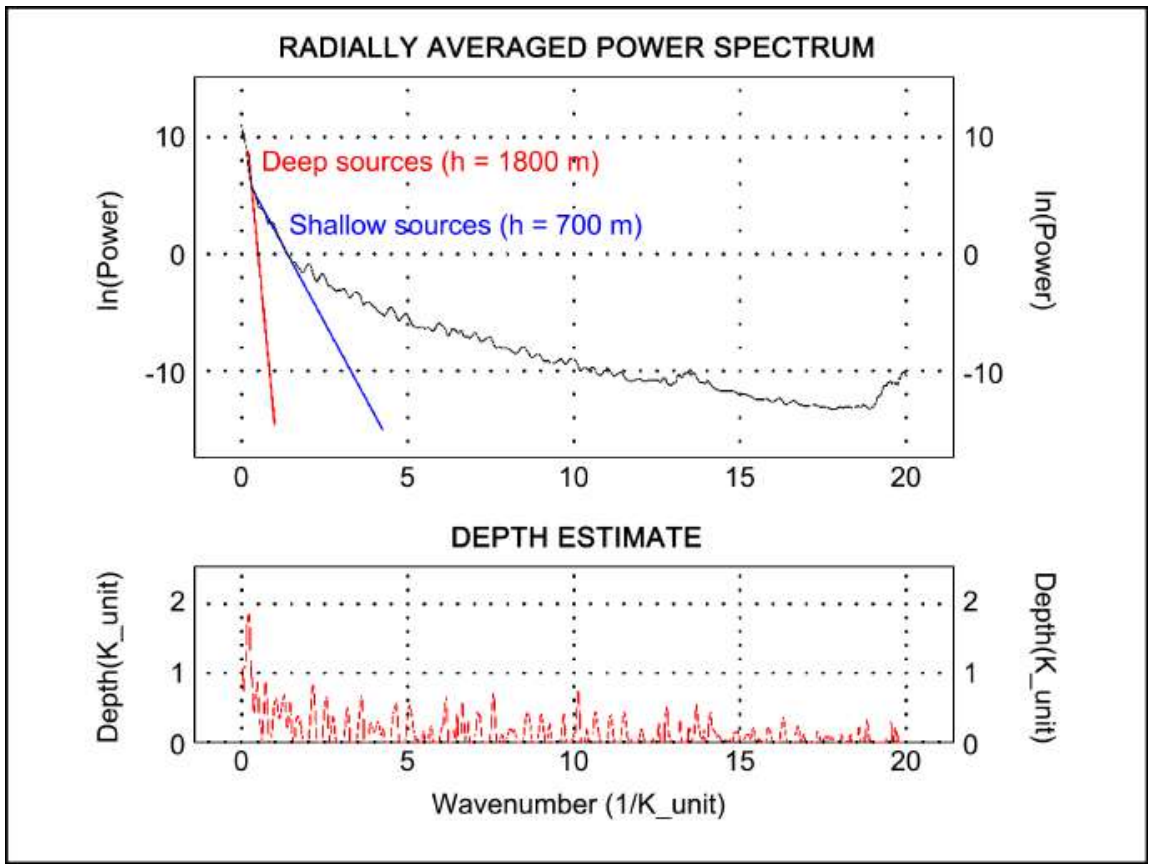

Figure 4. Radially averaged power spectrum and depth estimate of the RTP airborne magnetic map of the area around G. El-Niteishat, Central Eastern Desert, Egypt.

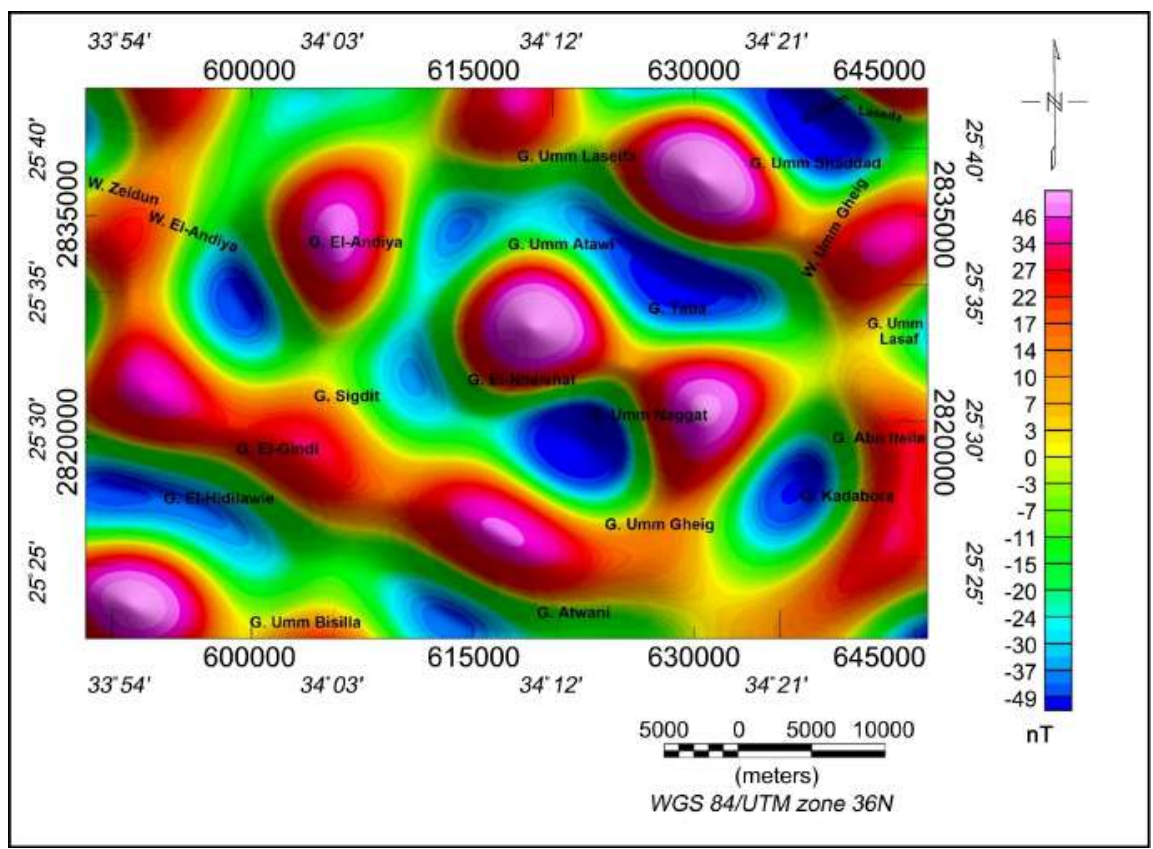

Figure 5. Residual airborne magnetic map of the area around G. El-Niteishat, Central Eastern Desert, Egypt. 


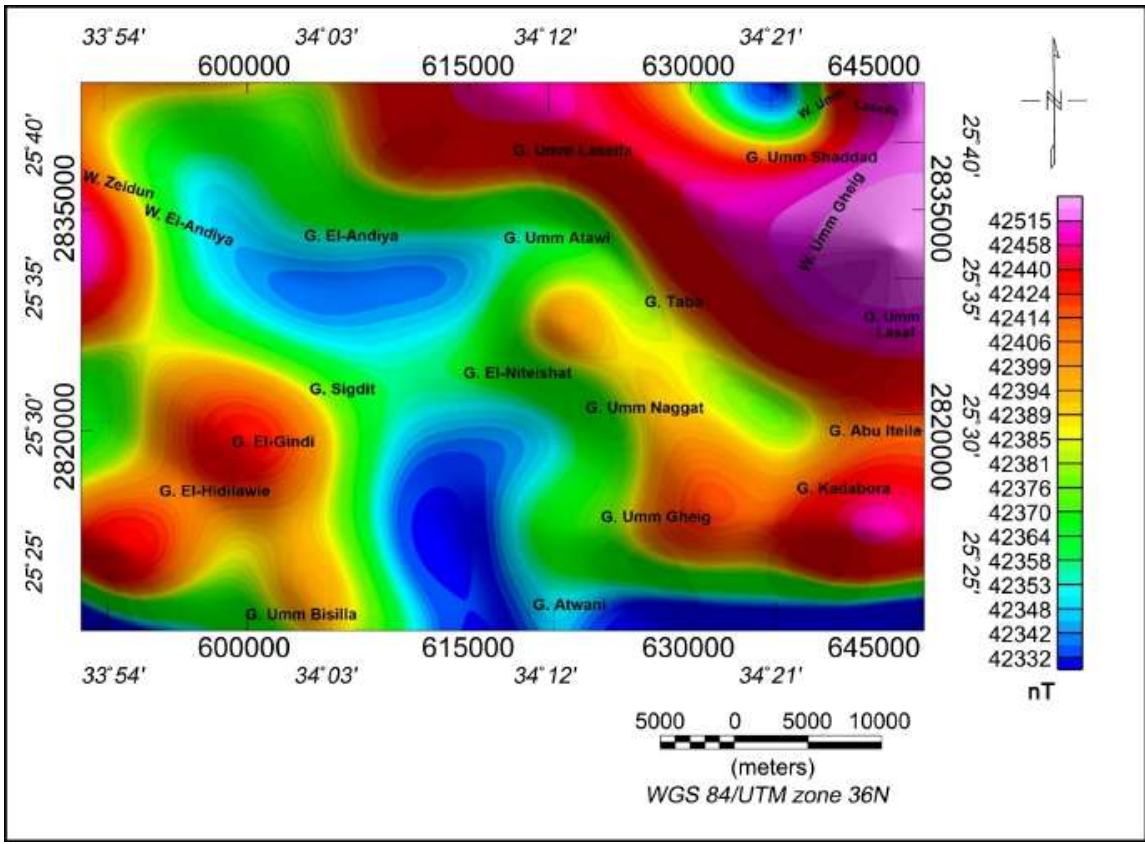

Figure 6. Regional airborne magnetic map of the area around G. El-Niteishat, Central Eastern Desert, Egypt.

\subsubsection{First Vertical Derivative (FVD) Map}

The first vertical derivative filter was applied for the reduced to the north magnetic pole (RTP) data to enhancement the near-surface lineament features such as shear zones, contacts, dykes and faults. The first vertical derivative map (Figure 7) shows gradient values varying between $-1.057 \mathrm{nT} / \mathrm{m}$ and $2.040 \mathrm{nT} / \mathrm{m}$. Three levels of the gradient are displayed as high positive values (pink), intermediate (green) and low negative values (blue). This map displays many semi-circular and linear magnetic features.

Three semi-circular features with high magnitude are observed at the western part of the area, that lie south W. Zeidun, southwest G. El-Hidilawie and G. ElGindi (Figure 7). These features may be related to basic rocks (serpentinites). Also, these features appeared to be structurally controlled.

An intermediate semi-circular feature occurs in the study area between G. Kadabora and G. Umm Lasaf at the eastern part (Figure 7), which is corresponding geologically to calc-alkaline granite at the surface. The contact of this feature with other rocks is clearly defined.

A linear magnetic feature with narrow width and NNW-SSE direction occurs at the western part of the study area (Figure 7). It may represent a buried basic dyke. Other high positive values occur at northern, eastern, southern and central parts of the study area, they are related to surface and subsurface basic rocks. These high positive values take different trends such as NW-SE, NE-SW, E-W and N-S.

Structural features like contacts, faults and shear zones can be deduced from the first vertical derivative map (Figure 7). Therefore, this technique is useful for extracting the structural lineman features. 


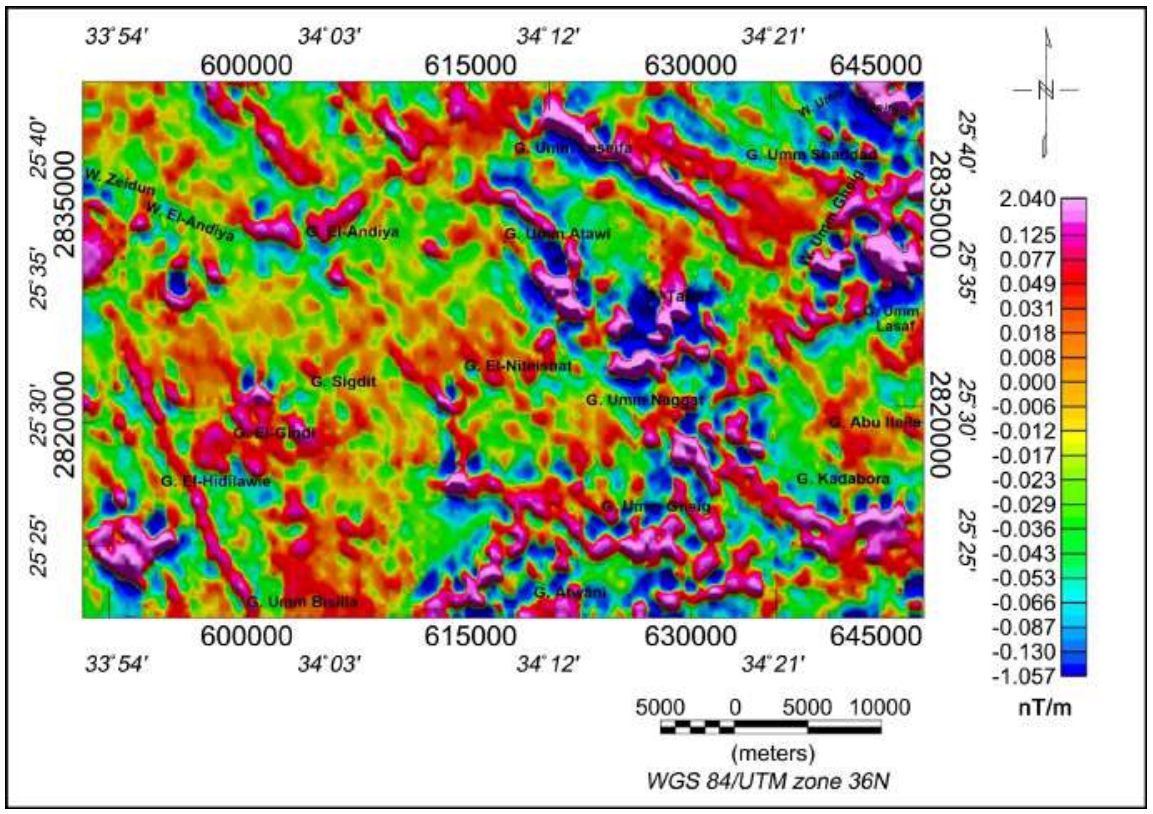

Figure 7. First vertical derivative (FVD) airborne magnetic map of the area around G. El-Niteishat, Central Eastern Desert, Egypt.

\subsubsection{Horizontal Gradient Magnitude (HGM) Map}

Horizontal gradient magnitude map (Figure 8) displays high gradient values (pink) with amplitude peak of $1.167 \mathrm{nT} / \mathrm{m}$, which may represent the magnetic features. The high values have variable amplitudes and shapes. The main trends of these values are NW-SE, NNW-SSE, NE-SW and E-W.

Semi-circular and ellipsoidal anomalies with high amplitude are located at south W. Zeidun, southwest G. El-Hidilawie, G. El-Gindi, G. Umm Lasaf and south G. Kadabora (Figure 8). They may due to outcrops and/or subsurface magnetic structures. Also, these anomalies can be classified as structurally controlled by faults.

A semi-circular anomaly is found at the eastern part of the map, along the area between G. Kadabora and G. Umm Lasaf. This anomaly is bounded by high amplitude gradient values, which are corresponding to faults and contacts (Figure 8).

Linear high amplitude gradient anomalies are observed on the HGM map (Figure 8). These anomalies are related to different structural and lithological features such as shear zones, faults and dykes located at the surface and subsurface in the study area.

\subsubsection{Tilt Derivative (TDR) Map}

Tilt derivative (TDR) filter is used for delineating the geologic structures, which may be linked to shallow structural lineaments and/or mineral exploration (Figure 9). This is because of the TDR concern on the detection of horizontal edges of the magnetic bodies or structures. The zero-contour line shows the horizontal location of the lateral change in magnetic susceptibility between positive and negative magnetic bodies (Figure 9). 


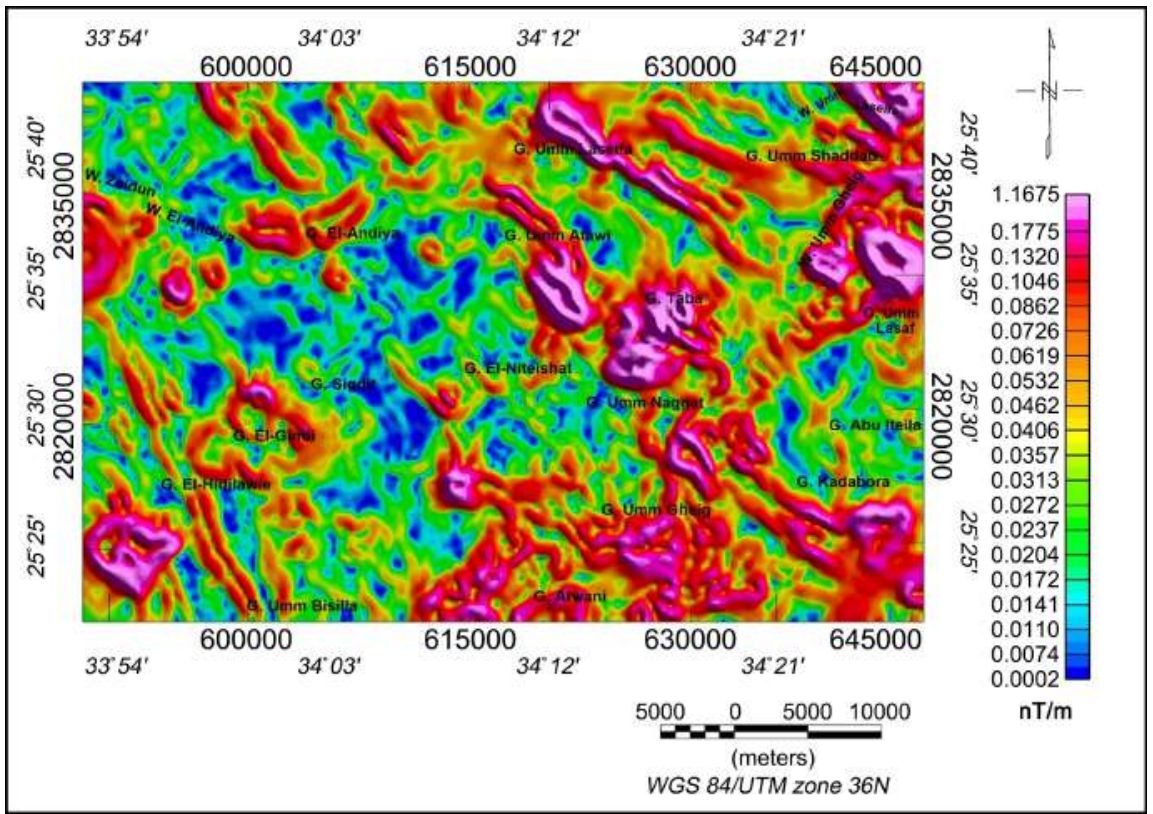

Figure 8. Horizontal gradient magnitude (HGM) airborne magnetic map of the area around G. El-Niteishat, Central Eastern Desert, Egypt.

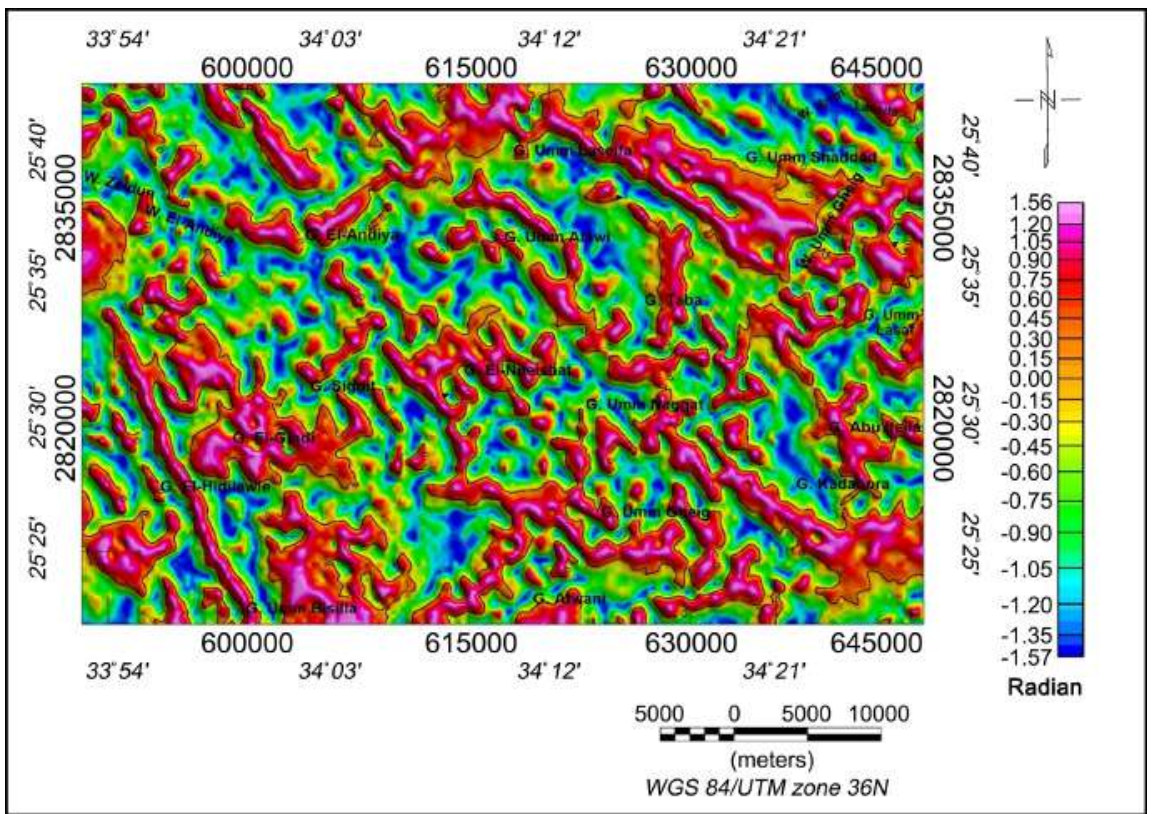

Figure 9. Tilt Derivative (TDR) airborne magnetic map of the area around G. El-Niteishat, Central Eastern Desert, Egypt.

\subsubsection{Near Surface Map}

The residual map at level of $100 \mathrm{~m}$ (Figure 10) is constructed by subtracting the upward continuation map of $100 \mathrm{~m}$ from the RTP map. This map is useful in the emphasizing of magnetic source bodies and structural lineaments (Finn and Horton, 2015). This map is exploited to highlights the near-surface structural lineaments of the study area. It shows high similarity with the first vertical derivative map and confirms the same results. 


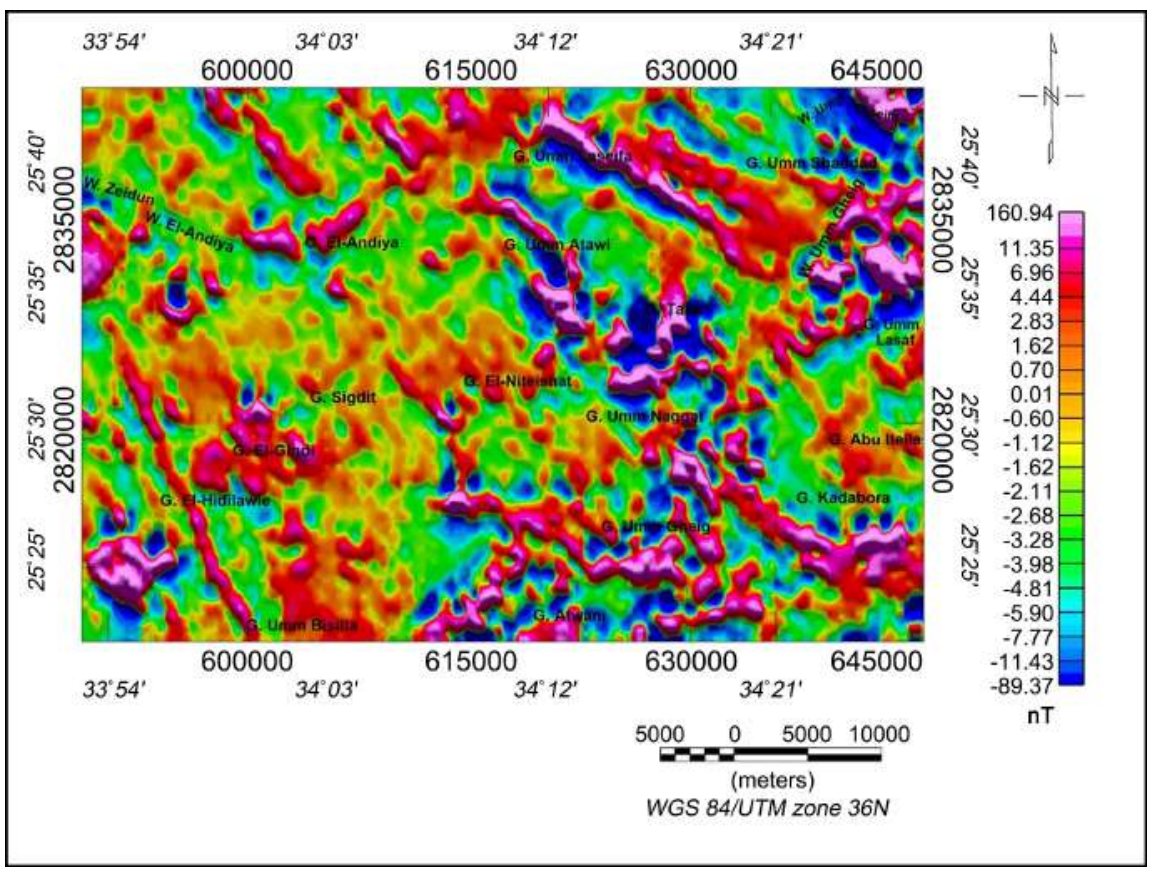

Figure 10. Near surface (NS) airborne magnetic map of the area around G. El-Niteishat, Central Eastern Desert, Egypt.

\subsection{Interpretation of Remote Sensing Data}

The interpretation of spectral data for detecting the target from different satellite sensors as Landsat Thematic Mapper (TM), Enhanced Thematic Mapper (ETM+) and ASTER imagery was applied. Integration of different images ASTER, and Landsat ETM) were used for mapping the mineral characters zones [27] [28].

One scene of Landsat-7 covering the selected area (p174) was used (30 m resolution). False-color composite image of band combination 7, 4, 2 in red (R), green $(\mathrm{G})$ and blue $(\mathrm{B})$ is used for representing the rock unit boundaries in the selected area. This combination shows the variation of felsic, mafic and wadi deposits. Felsic rocks reflect a reddish-brown to dark red color, the mafic rocks are dark and the wadi deposits are bright color (Figure 11).

For detecting the mineralization zones, band ratio is almost applied to represent the spectral characters of the alteration zones due to absorbing bands of their altered minerals. Applying of the enhanced satellite images of Landsat-7, the iron-bearing (ferrous and ferric oxides) minerals are detecting from applying band ratios 3/5, 5/4 and 3/1 [29] [30]. Moreover, the band ratio of 5/7 was used to pick up the high values of the hydroxyl-bearing minerals (epidotes, chlorites, kaolinite and muscovite) (e.g., [31]). In the current study, the band ratio 5/4 was used for detecting the alteration zone of ferrous and ferric minerals in the study area as shown in Figure 12 in which these alteration areas are represented by the very clear white color surrounded by the grey color. For detecting the Alteration zone of the hydroxyl $(\mathrm{OH})$-bearing minerals, the band ratio 5/7 is used, as shown in Figure 13. 


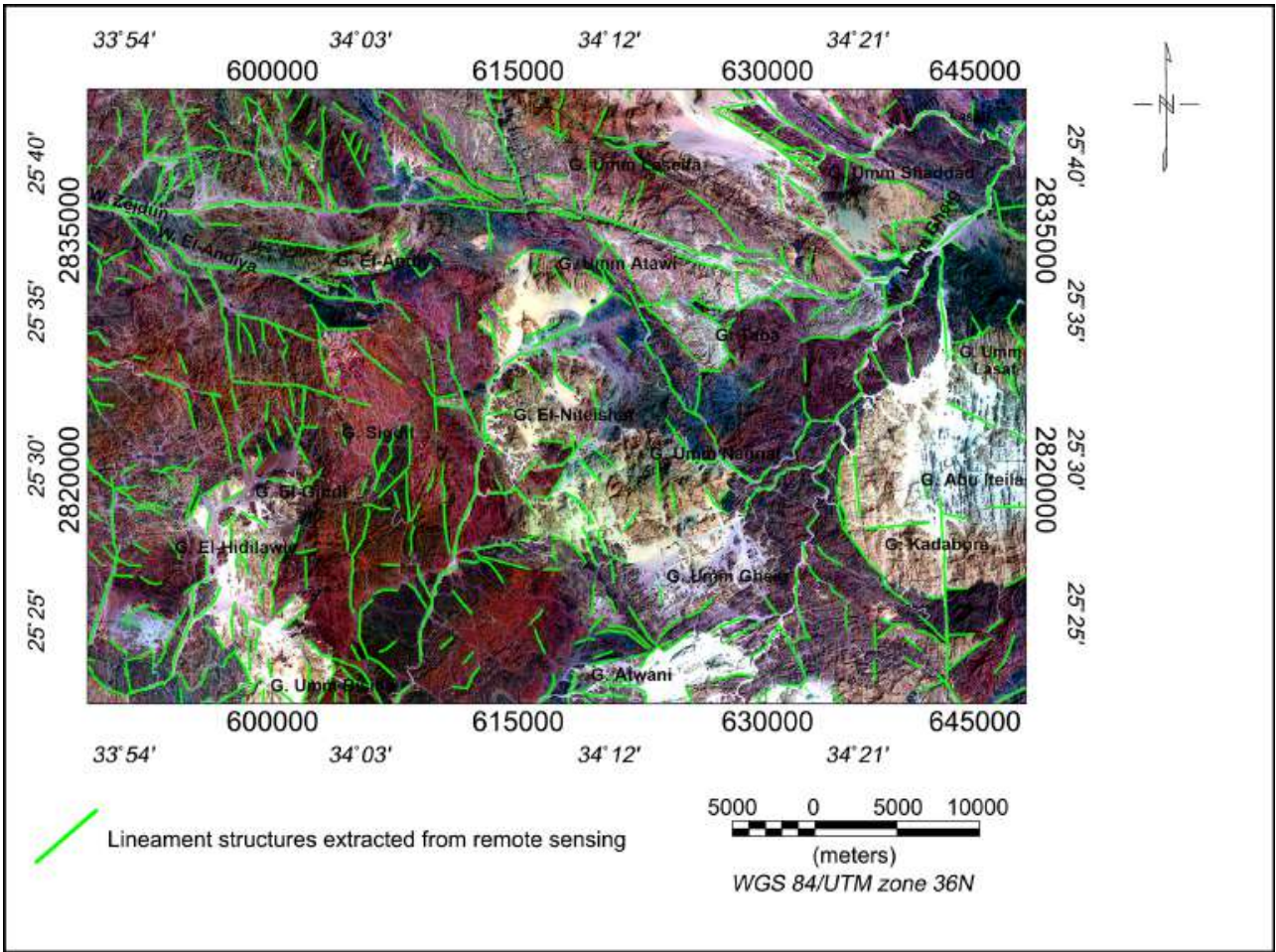

Figure 11. False color composite image of band combination 7, 4, 2 in R, G, and B with lineaments structures extracted from remote sensing of the area around G. El-Niteishat, Central Eastern Desert, Egypt.

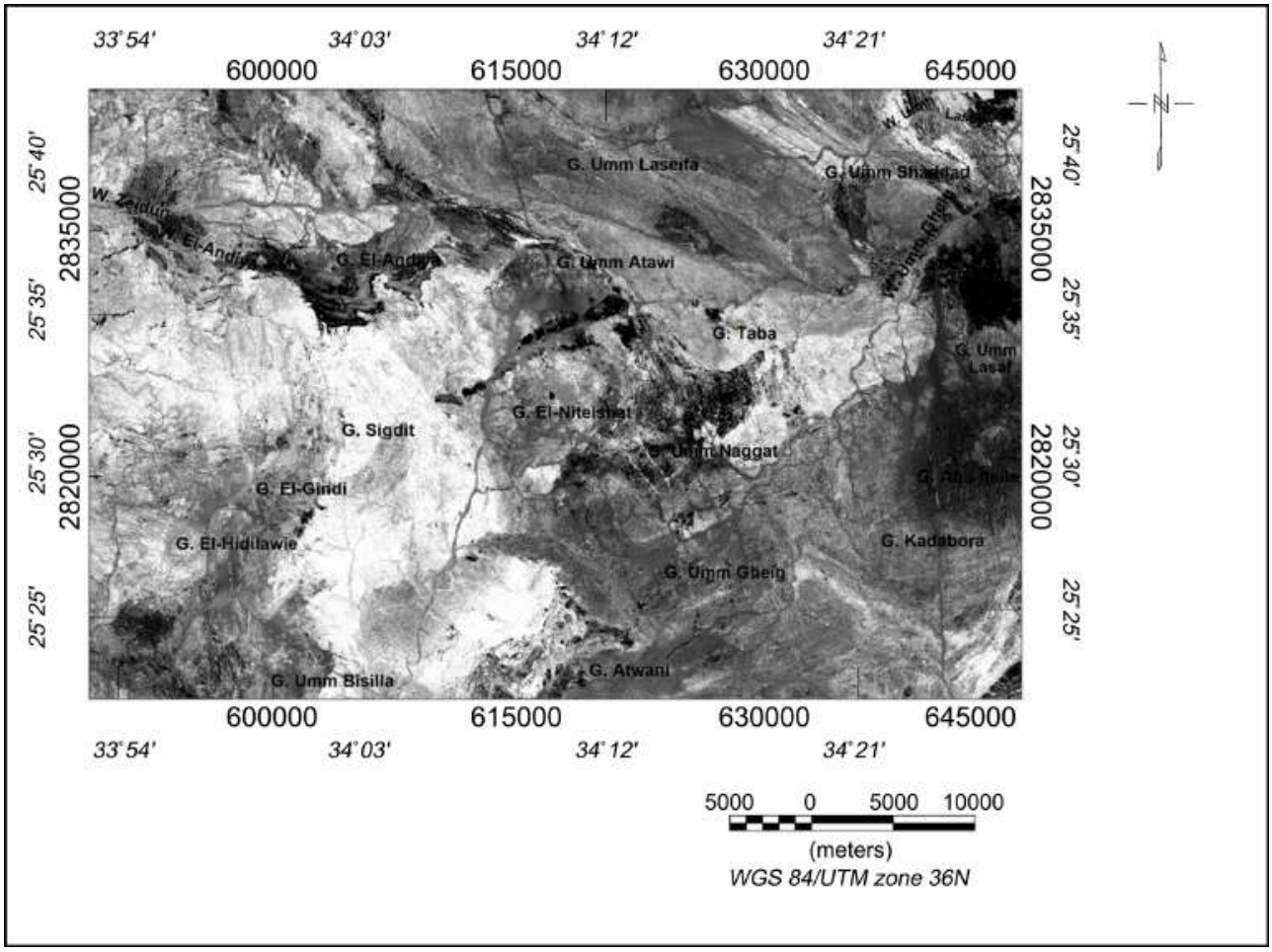

Figure 12. Extraction alteration zone of ferrous and ferric minerals with band ratio 5/4 (Fe image) -in grey color, the alteration zone represented by the clear white color, the area around G. El-Niteishat, Central Eastern Desert, Egypt. 


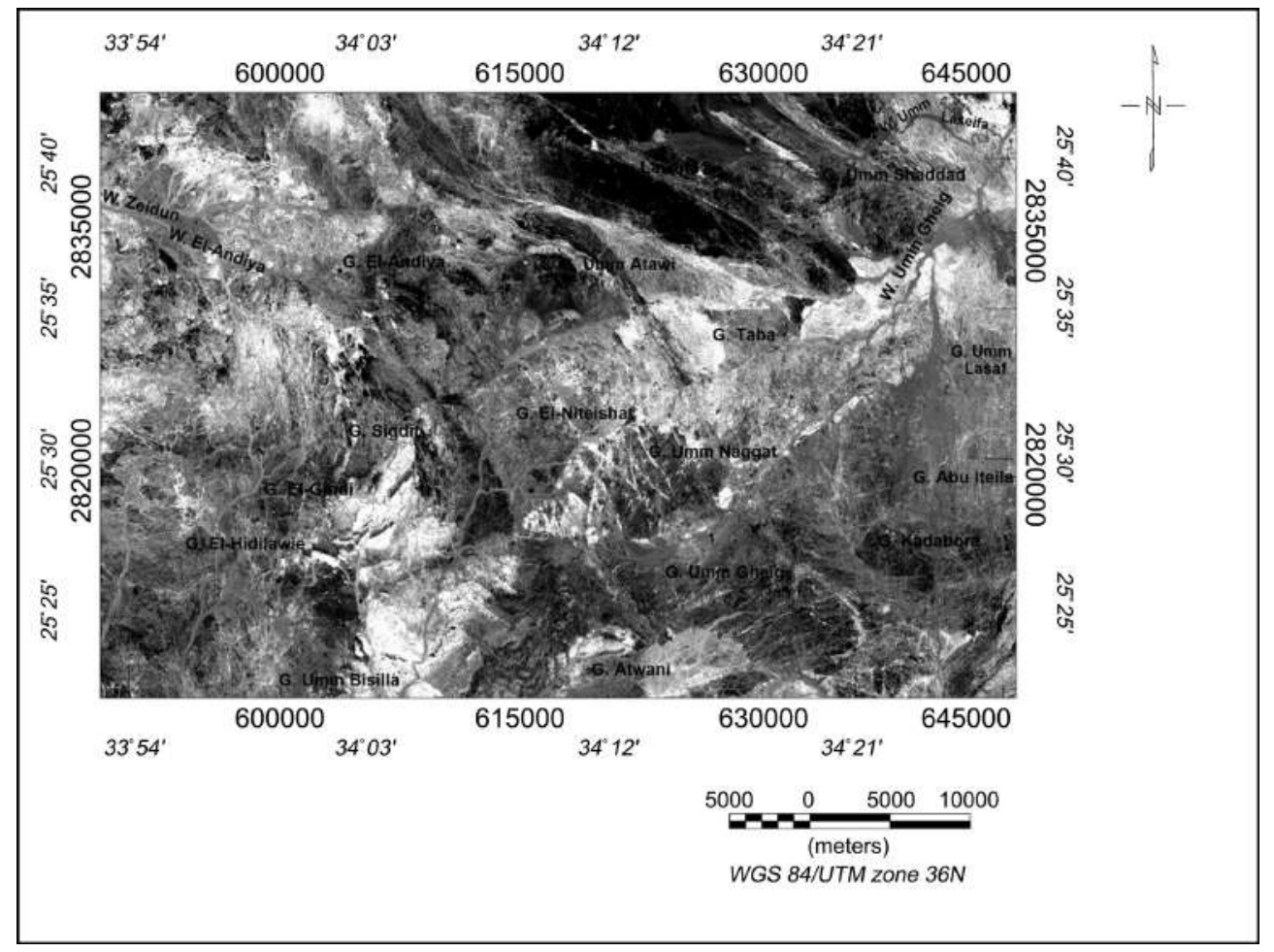

Figure 13. Extraction alteration zone of hydroxyl-bearing minerals with band ratio 5/7 (OH-image) -in gray color, the alteration zone represented by the clear white color, the area around G. El-Niteishat, Central Eastern Desert, Egypt.

Another band ratio has been applied for representing the final alteration zone in the study area, this band ration displayed the OH-bearing menials (5/7 ratio) in $\mathrm{R}$, the Fe-bearing menials (5/4 ratio) in $\mathrm{B}$ and $\mathrm{OH}+\mathrm{F}(5 / 7+5 / 4)$ in $\mathrm{G}$ (Figure 14). The final image shows the alteration zones of ferric, ferrous and $\mathrm{OH}$-bearing minerals, which appear in very light pink color (Figure 15). The clay minerals content in the sedimentary rocks and wadi deposits, both represented by the dark green color (Figure 15).

In addition to band ratios, principal component analysis (PCA) was applied to get specific results about the alteration zones. PCA is an important technique that provided simple information on multispectral datasets. This method was used to reduce the abundance of information between the different bands ([32] [33]). Crosta and Moore (1989) represented the advantage of oriented principal components selection, that used for evaluation of PCA to determine which of the principal component images allowed concentrating data immediately concerning with the theoretical spectral signatures of certain objectives [34]. Loughlin (1991) deduced that the analysis of these images showed the target zones in bright or dark pixels [32]. Based on the experiment results, the iron-bearing minerals and $\mathrm{OH}$-bearing minerals showed absorption features in specific bands rather than another. This technique requires no atmospheric correction or detail information of the spectral characters of specific targets. It is an efficient tool for describing alteration zones from the obtained data. 


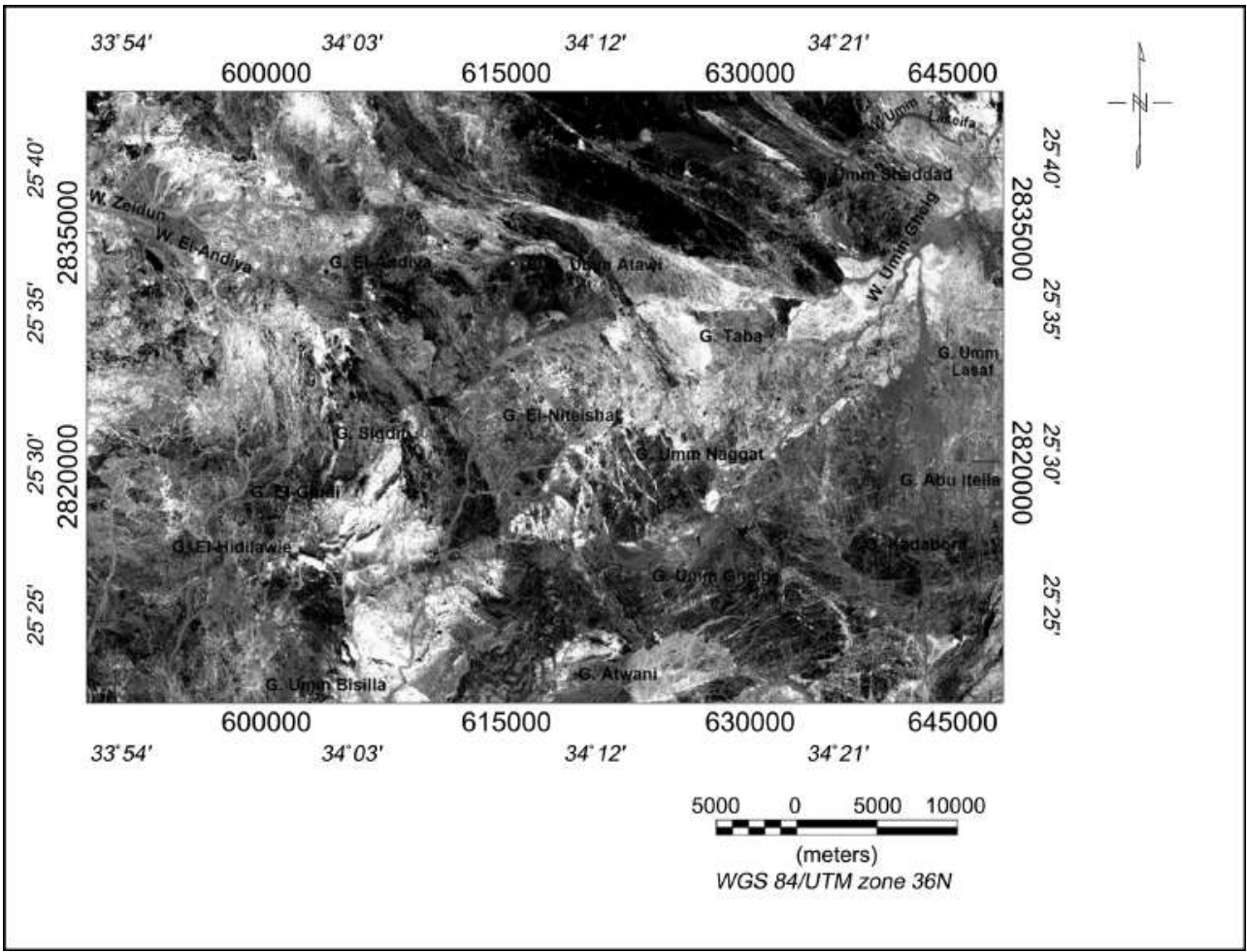

Figure 14. Extraction alteration zone of ferric and hydroxyl-bearing minerals with band ratio $5 / 4+$ $5 / 7$ ( Fe $+\mathrm{OH}$ image), the area around G. El-Niteishat, Central Eastern Desert, Egypt.

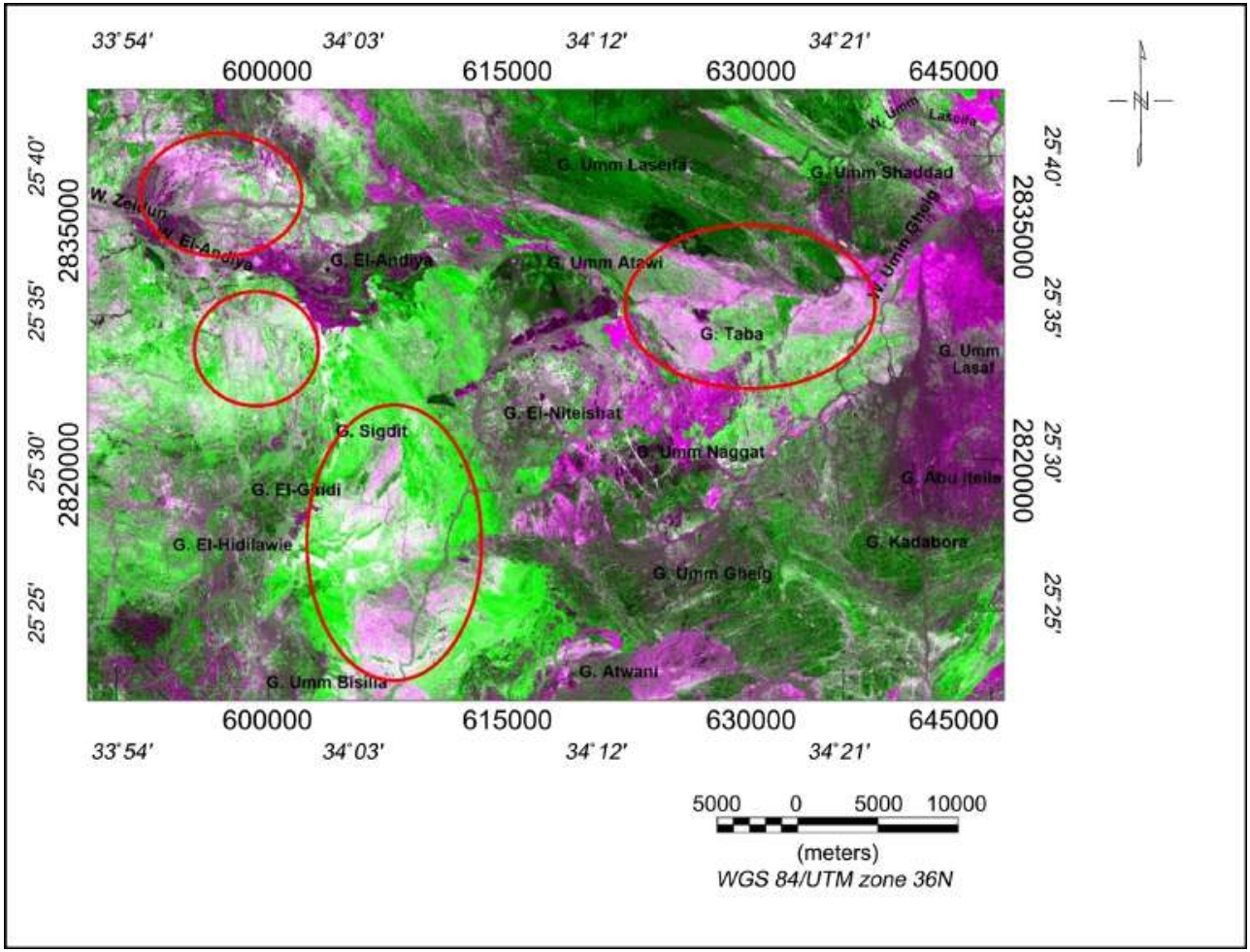

Figure 15. Band ratio image showing the alteration areas of ore deposits mineralization represented with very light pink color after displaying $\mathrm{OH}(\mathrm{R}), \mathrm{F}(\mathrm{B})$ and $\mathrm{OH}+\mathrm{F}(\mathrm{G})$, the area around $\mathrm{G}$. El-Niteishat, Central Eastern Desert, Egypt. 
Using the PCA method, the hydroxide minerals, ferric and ferrous minerals can be delineated from the selected bands with their principal components. For detecting the alteration zones of hydroxide minerals, the bands of 1, 4, 5, 7 were selected using PCA (Table 1) and iron-bearing minerals, bands 1, 3, 4, 5 (Table 2). To get good contrast for the alteration areas, suitable eigenvectors from different bands were selected.

False-color composite image (Crosta alteration image) was constructed after utilizing the $\mathrm{OH}$-bearing minerals (H-image) in Red (Figure 13), the iron-bearing oxides (F-image) in Blue (Figure 12) and the $\mathrm{H}+\mathrm{F}$ image in green (Figure 14). This map is used to delineate the alteration zones and detect the richer zones of the iron oxides and $\mathrm{OH}$-bearing minerals. The alteration areas resulting from this technique can be shown in Figure 16. The Alteration zone of the iron bearing minerals and hydroxide-bearing minerals richer zones appear by brown color.

From the two Figure 12 and Figure 13, the alteration zones of the iron-bearing menials and the Hydroxides-bearing menials were represented by brown color in the Crosta image (Figure 16) and represented by very light pink color in the final alteration zone image (Figure 15) at exactly in the same locations in the study area. There is a good correlation between the two images about the locations of the alteration area in the study area.

The iron-bearing oxides and the $\mathrm{OH}$-bearing minerals are commonly accompanied by ore economic deposits such as $\mathrm{Au}, \mathrm{Pb}, \mathrm{Fe}, \mathrm{Cr}, \mathrm{Cu}$ and many other economic minerals. So, using the analysis of the satellite image and applying some method of the enhancements of these images help to delineate the location of the ore deposits minerals in the study area.

Table 1. PCA of the selected bands 1, 4, 5, and 7 of Landsat-7.

\begin{tabular}{cccccc}
\hline $\begin{array}{c}\text { Eigen } \\
\text { vector }\end{array}$ & $\begin{array}{c}\text { Band } \\
1\end{array}$ & $\begin{array}{c}\text { Band } \\
4\end{array}$ & $\begin{array}{c}\text { Band } \\
5\end{array}$ & $\begin{array}{c}\text { Band } \\
7\end{array}$ & $\begin{array}{c}\text { Eigen } \\
\%\end{array}$ \\
\hline PC1 & 0.431 & 0.522 & 0.523 & 0.517 & 89.67 \\
PC2 & 0.840 & 0.065 & -0.373 & -0.389 & 7.75 \\
PC3 & 0.328 & -0.844 & 0.200 & 0.375 & 1.88 \\
PC4 & -0.029 & 0.108 & -0.740 & 0.664 & 0.70 \\
\hline
\end{tabular}

Table 2. PCA of the selected bands 1, 3, 4, and 5 of Landsat-7.

\begin{tabular}{cccccc}
\hline $\begin{array}{c}\text { Eigen } \\
\text { vector }\end{array}$ & $\begin{array}{c}\text { Band } \\
1\end{array}$ & $\begin{array}{c}\text { Band } \\
3\end{array}$ & $\begin{array}{c}\text { Band } \\
4\end{array}$ & $\begin{array}{c}\text { Band } \\
5\end{array}$ & $\begin{array}{c}\text { Eigen } \\
\%\end{array}$ \\
\hline PC1 & 0.446 & 0.522 & 0.525 & 0.504 & 91.33 \\
PC2 & 0.790 & 0.049 & -0.153 & -0.591 & 6.38 \\
PC3 & 0.400 & -0.442 & -0.502 & 0.627 & 2.11 \\
PC4 & 0.130 & -0.728 & 0.670 & -0.060 & 0.18 \\
\hline
\end{tabular}




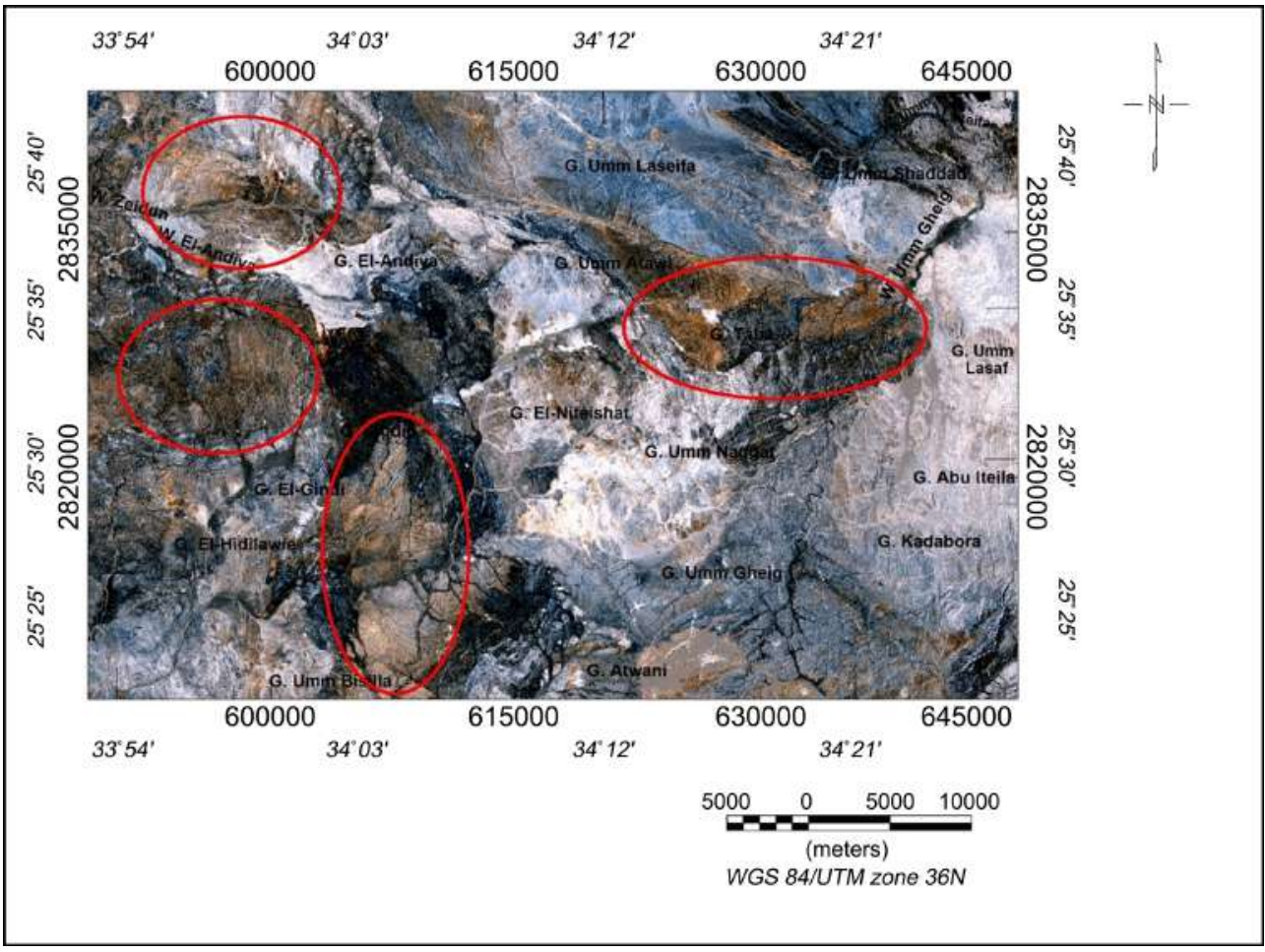

Figure 16. False color composite image using Crosta technique displaying $\mathrm{OH}(\mathrm{R}), \mathrm{F}(\mathrm{B})$ and $\mathrm{OH}+$ F (G), the area around G. El-Niteishat, Central Eastern Desert, Egypt.

\subsection{Structural Lineaments Analysis}

Structural lineament analysis has an important role in mineral exploration where most of the mineral deposits are controlled by structures directly or indirectly. To study structural lineaments of the study area; surface, shallow and deep lineament structures were deduced from the geologic, remote sensing, RTP, near-surface, residual and regional maps. These lineaments were presented as rose diagrams (Figure 17).

The rose diagrams of surface lineament structures (Figure 17(a) and Figure 17(b)) illustrate that the common trends are NW-SE, NE-SW, E-W and N-S. These trends also appeared in the rose diagrams of the shallow and deep lineament structures (Figures 17(c)-(e) and Figure 17(f)). This confirms that these trends extended from the surface to deep depths.

The E-W trend is observed at the rose diagram of the regional map (Figure $17(\mathrm{f})$ ) as a dominant structure which suggests that this trend is considered as the deepest structure in the study area. According to Meshref (1990), the NW-SE, NE-SW trends represent the favorable structures for mineral Exploration.

\subsection{Data Results Integration}

Through the results that are obtained from airborne magnetic and remote sensing data, it can be inferred the following:

1) The analysis of remote sensing data displays the alteration zones as red circles (Figure 18). These zones show the locations of concentrations of mineral 
deposits in the study area. Figure 18 shows that the known mineralization sites previously recorded on maps are located in or near alteration zones, indicating that the areas inferred from the current study are promising for mineralization exploration.

2) The integrated map (Figure 18) shows that the main structural trends in alteration zones are taking the NW-SE and NE-SW directions. Structural lineaments have the main effect on mineral exploration, as these lineaments act as channels for hydrothermal solutions that carry mineralization. The results of the present study show that there is an agreement between the structural lineaments and alteration zones, which is the main objective of this study.

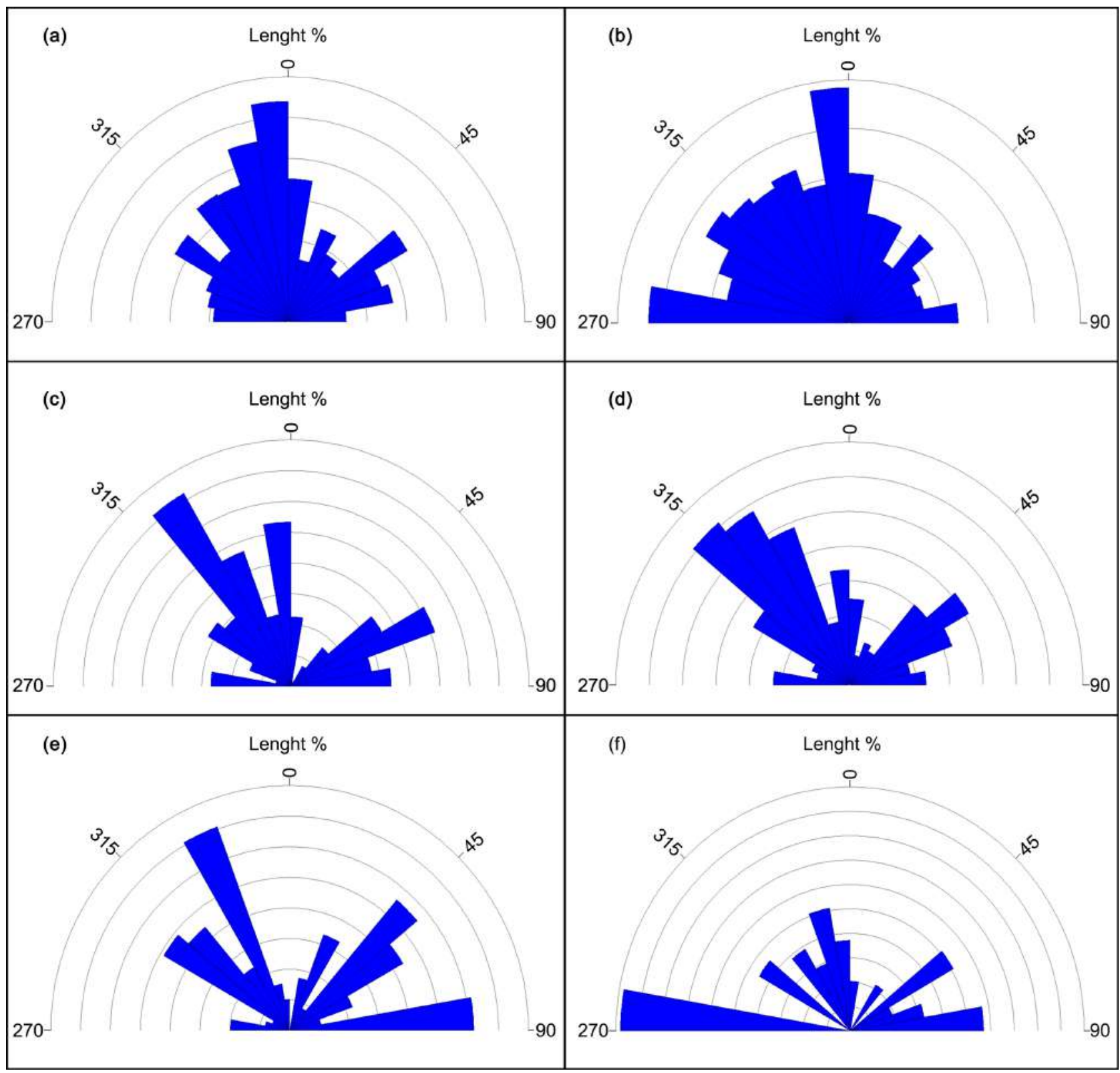

Figure 17. Rose diagrams of structural lineaments that obtained from (a) geology, (b) remote sensing, (c) RTP, (d) near surface, (e) residual and (f) regional maps of the area around G. El-Niteishat, Central Eastern Desert, Egypt. 


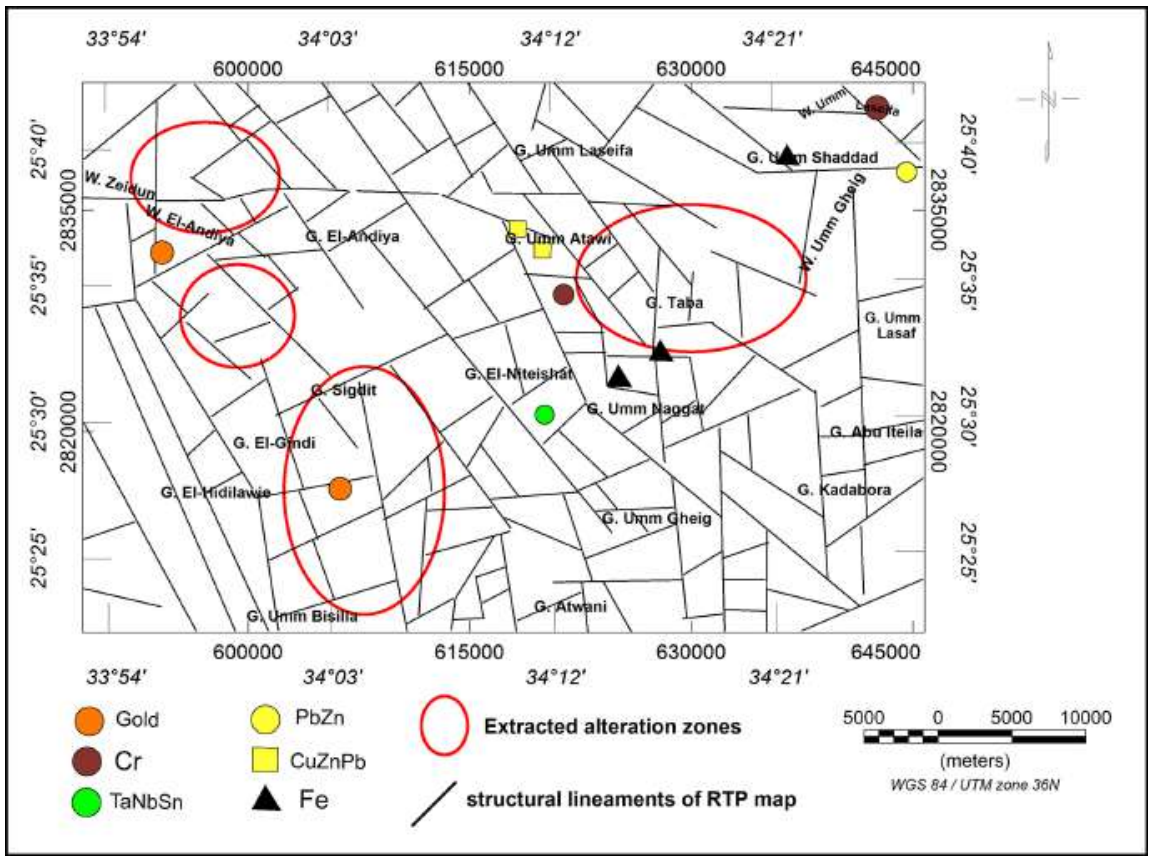

Figure 18. Integrated results of airborne magnetic and remote sensing data of the area around G. El-Niteishat, Central Eastern Desert, Egypt.

\section{Conclusions}

The analyses of RTP, residual and regional maps show the magnetic features of rocks and the structural lineaments which may associate with mineralization zones. Also, the depths of the shallow and deep magnetic anomalies are estimated by the radially averaged power spectrum. The first vertical derivative (FVD), horizontal gradient magnitude (HGM), tilt derivative (TDR) and near-surface maps illustrated the locations of the magnetic anomalies and shallow structural lineaments. The remote sensing images revealed the boundaries of rock units, surface structural lineaments and alteration areas.

The results of the application of different magnetic and remote sensing techniques revealed the following:

1) The computed power spectrum of the RTP airborne magnetic data revealed that the estimated average depths for shallow and deep magnetic causative bodies were $700 \mathrm{~m}$ and $1800 \mathrm{~m}$ respectively.

2) Through the implementation of different processing and filter techniques such as the first vertical derivative (FVD), horizontal gradient magnitude (HGM), tilt derivative (TDR) and near-surface for the airborne magnetic data. The structural lineaments that affected the study area were extracted and represented as rose diagrams. These structural lineaments played an important role in the mineral distributions. Also, these lineaments were correlated with known mineralization that was found from the previous studies. Some of the known mineralization coincided with the extracted structural lineaments.

3) The processing of remote sensing data displayed the alteration zones of ferric, ferrous and hydroxyl-minerals, which appeared in a very light pink color. The 
clay minerals content in the sedimentary rocks and wadi deposits are represented by dark green color.

4) Crosta alteration image showed the alteration zones of the iron-bearing minerals and hydroxide-bearing mineral richer zones appeared by brown color.

5) The analysis of the structural lineaments as deduced from geologic, remote sensing, RTP, near surface, residual and regional maps for the study area are taking the NW-SE, NE-SW, E-W and N-S directions.

6) It is recommended to carry out geochemical and geophysical studies to test the type and degree of mineralization especially in the alteration zones obtained from the present study.

\section{Acknowledgements}

Firstly, we thank Allah who helps us to finish this study, we also thank our colleges in ground geophysics department who give us the requested information about the study area. Finally, many thanks to everyone supported us to finish the present paper in a good final form.

\section{Conflicts of Interest}

The authors declare no conflicts of interest regarding the publication of this paper.

\section{References}

[1] Ghieth, B.M. (1995) The Application of Aerial Spectrometric and Magnetometric Data to the Study of Association of Mineral Deposits in Gebel El Sebai Area, Eastern Desert, Egypt. M.Sc. Thesis, Faculty of Science, Ain Shams University, Cairo, $140 \mathrm{p}$.

[2] Ghieth, B.M. (1998) Application of Some Geophysical Techniques in Depicting Geologic, Tectonic Setting and Ore Mineralization Potentiality of G. Abu Iteila, Central Eastern Desert, Egypt. Ph.D. Thesis, Faculty of Science, El Mansoura University, Mansoura, $120 \mathrm{p}$.

[3] Gaafar, I.M. (2015) Integration of Geophysical and Geological Data for Delimitation of Mineralized Zones in Um Naggat Area, Central Eastern Desert, Egypt. NRIAG Journal of Astronomy and Geophysics, 4, 86-99. https://doi.org/10.1016/j.nrjag.2015.04.004

[4] Sabet, A.H., Zhukov, M.A., Babourin, L.M. and Mansour, M.G. (1976) Rare Metal Apogranites in Um Naggat Massif. Egyptian Geological Survey, Annals, 6, 191-200.

[5] Aboelkhair, H., Hasan, E. and Sehsah, H. (2014) Mapping of Structurally Controlled Uranium Mineralization in Kadabora Granite, Central Eastern Desert, Egypt Using Remote Sensing and Gamma Ray Spectrometry Data. The Open Geology Journal, 8, 54-68. https://doi.org/10.2174/1874262901408010054

[6] Aboelkhair, H., Saleh, G.M., Selim, E. and Mogahed, A.N. (2020) Using Airborne Gamma-Ray Spectrometry for Mapping Radioactive Zones in G. Kadabora Area, Central Eastern Desert, Egypt. International Journal of Mining Science (IJMS), 6, 1-10. https://doi.org/10.20431/2454-9460.0602001

[7] Haldar, S.K. (2018) Mineral Exploration: Principles and Applications. 2nd Edition, Elsevier, Amsterdam, 378. 
[8] Assran, A.S.M., El Qassas, R.A.Y. and Yousef, M.H.M. (2019) Detection of Prospective Areas for Mineralization Deposits Using Image Analysis Technique of Aeromagnetic Data around Marsa Alam-Idfu Road, Eastern Desert, Egypt. Egyptian Journal of Petroleum, 28, 61-69. https://doi.org/10.1016/j.ejpe.2018.11.002

[9] Abuelnaga, H.S., Aboulela, H., El-Sawy, K.E. and El Qassas, R.A.Y. (2019) Detection of Structural Setting That Controlling Hammam Faroun Area, Using Aeromagnetic and Seismicity Data, Gulf of Suez, Egypt. Journal of African Earth Sciences, 158, Article ID: 103560. https://doi.org/10.1016/j.jafrearsci.2019.103560

[10] Eldosouky, A.M., Sehsah, H., Elkhateeb, S.O. and Pour, A.B. (2020) Integrating Aeromagnetic Data and Landsat-8 Imagery for Detection of Post-Accretionary Shear Zones Controlling Hydrothermal Alterations: The Allaqi-Heiani Suture Zone, South Eastern Desert, Egypt. Advances in Space Research, 65, 1008-1024.

https://doi.org/10.1016/j.asr.2019.10.030

[11] Eldosouky, A.M., Elkhateeb, S.O., Ali, A. and Kharbish, S. (2020) Enhancing Linear Features in Aeromagnetic Data Using Directional Horizontal Gradient at Wadi Haimur Area, South Eastern Desert, Egypt. Carpathian Journal of Earth and Environmental Sciences, 15, 323-326. https://doi.org/10.26471/cjees/2020/015/132

[12] Shi, D.L. and Zhang, Y.J. (1991) Multivariate Geological Comprehensive Images Processing Method in the Application of the Mineral Resource Prediction. The Computer Application Study on Geology Science, 127-134.

[13] Zhang, X., Pazner, M. and Duke, N. (2007) Lithologic and Mineral Information Extraction for Gold Exploration Using ASTER Data in the South Chocolate Mountains (California) Photogramm. Remote Sensing, 62, 271-282. https://doi.org/10.1016/j.isprsjprs.2007.04.004

[14] Conoco Coral Corporation and the Egyptian General Petroleum Corporation (EGPC) (1987) Geological Map of Egypt, Scale 1: 500000-NG 36 SE-GEBEL HAMATA.

[15] Egyptian Geological Survey and Mining Authority (EGSMA) (1983) Metallogenic Map of the Aswan Quadrangle, Egypt, Scale 1: 500000.

[16] Hume, W.F. (1937) Geology of Egypt: Survey of Egypt, Cairo, II (3): 689-990.

[17] Egyptian Geological Survey and Mining Authority (EGSMA) (1974) On the Result of Prospecting Work for Rare and Non-Ferrous Metals and Gold in the Area of Wadies Um Gheig, Sitra, El Dabbah and Abu Tundub. Internal Report.

[18] Hassanen, M.A., Moghazi, A.M., Hashad, M.H. and ElSayed, M.M. (2008) The Role of Crystal/Melt and Fluid Fractionation in the Genesis of Late Neoproterozoic Rare Metal-Bearing A-Type Granite of Um Naggat pluton, Eastern Desert, Egypt. Egyptian Mineralogist. (In Press)

[19] Abd El-Wahed, M.A., El Metwaly, L., Ali, K.A., Kamh, S. and Attia, M. (2019) The Structural Geometry and Metamorphic Evolution of the Umm Gheig Shear Belt, Central Eastern Desert, Egypt: Implications for Exhumation of Sibai Core Complex during Oblique Transpression. Arabian Journal of Geosciences, 12, 764. https://doi.org/10.1007/s12517-019-4760-y

[20] Hamimi, Z., Zoheir, B.A. and Younis, M.H. (2015) Polyphase Deformation History of the Eastern Desert Tectonic Terrane in Northeastern Africa. XII International Conference "New Ideas in Earth Sciences", Moscow, April 2015.

[21] Stern, R.J. (2017) Neoproterozoic Formation and Evolution of Eastern Desert Continental Crust-The Importance of the Infrastructure-Superstructure Transition. Journal of African Earth Sciences, 146, 15-27. https://doi.org/10.1016/j.jafrearsci.2017.01.001 
[22] Aero-Service (1984) Final Report on Airborne Magnetic and Radiation Survey in Eastern Desert, Egypt. Work Completed for the Egyptian General Petroleum Corporation (EGPC) Six Volumes, Aero-Service, Houston, Texas, USA.

[23] Gunn, P.J. (1975) Linear Transformation of Gravity and Magnetic Fields. Geophysical Prospecting, 23, 300-312. https://doi.org/10.1111/j.1365-2478.1975.tb01530.x

[24] Cordell, L. and Grauch, V.J.S. (1982) Mapping Basement Magnetization Zones from Aeromagnetic Data in the San Juan Basin, New Mexico. SEG Technical Program Expanded Abstracts, 246-247. https://doi.org/10.1190/1.1826915

[25] Cordell, L. and Grauch, V.J.S. (1985) Mapping Basement Magnetization Zones from Aeromagnetic Data in the San Juan Basin, New Mexico. In: Hinze, W.J., Ed., The Utility of Regional Gravity and Magnetic Anomaly Maps, Society of Exploration Geophysicists, Dallas, 181-197. https://doi.org/10.1190/1.0931830346.ch16

[26] Miller, H.G. and Singh, V. (1994) Potential Field Tilt: A New Concept for Location of Potential Field Sources. Journal of Applied Geophysics, 32, 213-217. https://doi.org/10.1016/0926-9851(94)90022-1

[27] Pour, A.B. and Hashim, M. (2014) ASTER, ALI and Hyperion Sensors Data for Lithological Mapping and Ore Minerals Exploration. SpringerPlus, 3, Article No. 130. https://doi.org/10.1186/2193-1801-3-130

[28] Pour, A.B. and Hashim, M. (2015) Structural Mapping Using PALSAR Data in the Central Gold Belt, Peninsular Malaysia. Ore Geology Reviews, 64, 13-22. https://doi.org/10.1016/j.oregeorev.2014.06.011

[29] Sultan, M., Arvidson, R.E. and Sturchio, N.C. (1986) Mapping of Serpentinites in the Eastern Desert of Egypt Using Landsat Thematic Mapper Data. Geology, 14, 995-999. https://doi.org/10.1130/0091-7613(1986)14<995:MOSITE>2.0.CO;2

[30] Abrams, M.J., Brown, D., Lepley, L. and Sadowski, R. (1983) Remote Sensing for Porphyry Copper Deposits in Southern Arizona. Economic Geology, 78, 591-604. https://doi.org/10.2113/gsecongeo.78.4.591

[31] Gupta, R.P. (2003) Remote Sensing Geology. 2nd Edition, Springer, Berlin. https://doi.org/10.1007/978-3-662-05283-9

[32] Loughlin, W.P. (1991) Principal Component Analysis for Alteration Mapping. Photogrammetric Engineering and Remote Sensing, 57, 1163-1169.

[33] Gomes, C., Delacourt, C., Allemand, P., Ledru, P. and Wackerle, R. (2005) Using Aster Remote Sensing Data Set for Geological Mapping in Namibia. Physics and Chemistry of the Earth, Parts $A / B / C, 30,97-108$. https://doi.org/10.1016/j.pce.2004.08.042

[34] Crosta, A. and McM, J. (1989) Enhancement of Landsat Thematic Mapper Imagery for Residual Soil Mapping SW Minais Gerais State, Brazil: Prospecting Case History in Greenstone Belt Terrain. Proceedings of 7 th ERIN Thematic Conference: Remote Sensing for Exploration Geology, Calgary, 2-6 October 1989, 1173-1187. 